\title{
BOLGAR AS AN OBJECT INSCRIBED ON THE UNESCO WORLD HERITAGE LIST (ON THE 5OTH ANNIVERSARY OF THE BOLGAR STATE HISTORICAL AND ARCHITECTURAL MUSEUM-RESERVE)
}

\author{
Rafael Mirgasimovich Valeev, \\ Kazan Federal University, \\ 18 Kremlevskaya Str., Kazan, 420008, Russian Federation, \\ valeev_rm@inbox.ru.
}

\begin{abstract}
The article is dedicated to the $50^{\text {th }}$ anniversary of the Bolgar Historical and Architectural MuseumReserve (1969). It systematizes the data on the history of the organization, which was the first to comprehensively study, preserve, conserve, and restore historical and cultural monuments of the Tatar people in the Tatar Autonomous Soviet Socialist Republic. The article presents a system of evidence, provided by the researchers from the Republic of Tatarstan, concerning the outstanding universal value of Bolgar. It served as a reason for the experts of the UNESCO World Heritage Committee to include the museum-reserve among the world-famous monuments.
\end{abstract}

Key words: Bolgar, outstanding universal value, criteria, integrity, originality, authenticity, protection and management.

Bolgar holds a unique place in the history of human civilization. The Bolgar Historical and Archaeological Complex is a center of world significance, its outstanding universal value was established by the decision of the $37^{\text {th }}$ Session of the UNESCO World Cultural and Natural Heritage Committee (2013, Phnom Penh, Cambodia). In 2014, in Qatar, this object was inscribed on the UNESCO World Heritage List and became the $27^{\text {th }}$ Russian and $1002^{\text {nd }}$ on this list at the $38^{\text {th }}$ Session of the Committee [Valeev].

Considerable source material on the history of this geocultural region has been accumulated over more than 150 years of archaeological studies of the Bolgar settlement. Systematic research began in 1864 when V. Tizengauzen made his first exploratory excavations [Tizengauzen], which continued in the late $19^{\text {th }}$ - early $20^{\text {th }}$ century. Later, in the 1930s-1940s they were supervised by A. Smirnov. The research was conducted up to the beginning of the $21^{\text {st }}$ century by Kazan scholars A. Khalikov, Z. Akchurina, A. Efimova, T. Khlebnikova, O. Khovanskaya, N. Kalinin, P. Starostin, and R. Sharifullin (see: [Khlebnikova]), which allowed representing the city of Bolgar in the $10^{\text {th }}$ and early $15^{\text {th }}$ centuries and pre-Bolgar monuments of the $5^{\text {th }}-7^{\text {th }}$ centuries [Starostin]. Monographic studies, carried out in 1996, 2001, 2008 [Gorod Bolgar, 1996], [Gorod Bolgar, 2001], [Gorod Bolgar, 2008], made it possible to analyze the huge archaeological, historical, and cultural material, to outline the directions for further research, and to determine the importance of Bolgar in the history of Tatarstan, Russia, and world history, its Outstanding Universal Value [Bolgarskii istoriko-arkheologicheskii kompleks].

The Bolgar settlement with its preserved ramparts and moats is located in the European part of Russia on the left bank of the Volga, $40 \mathrm{~km}$ south of the place where this river merges with the Kama, the settlement occupies the edge of the Volga indigenous terrace. In the east, it is adjacent to the modern city of Bolgar, the administrative center of the Spassky District in Tatarstan.

At the time of its origin, the city of Bolgar was located at the tip of the cape of the high Volga terrace, it was naturally and artificially strongly fortified, and had a fairly wide view towards the Volga. The well-defined fortifications of the settlement are several lines of the defense line, built at different times. The true remains of the fortifications, surrounding the city, have been preserved; today, they form a holistic historical and cultural landscape of the ancient settlement. By the middle of the $14^{\text {th }}$ century, the fortified part of the city had reached a considerable size; currently, the territory of the Bolgar Historical and Archaeological Complex is 443 hectares.

The state intends to preserve the integrity of the Complex and expands the boundaries of its buffer zone by incorporating early settlements, identified on the first river island, and by increas- 
ing its territory northwards to protect the panoramic view of the river Volga. Currently, the Complex buffer zone covers 12101 hectares, which makes it possible to embrace the entire territory of the Bolgar settlement, its adjacent historical territories, all their elements and values, unique viewpoints and perspectives, and to prevent the construction of multi-storeyed buildings that might damage the historical visual perception of the Complex [Khairutdinov].

\section{Complex \\ The outstanding universal value of the}

The Bolgar Complex is an outstanding sample of Eurasian geopolitical and historical transformations of the $10^{\text {th }}$ - early $21^{\text {st }}$ centuries, which played a key role in the formation of states and civilizations, the spread of Islam and Orthodoxy, the interactions of customs and cultural traditions of the modern Tatar and other peoples of the Eurasian continent. For over 15 centuries, it had a steady impact on the development of architecture, technology, monumental and decorative art, urban planning, and spiritual culture of Eurasia [Valeev].

In Bolgar, the long process of historical development from the $10^{\text {th }}$ to the $21^{\text {st }}$ centuries is not just fixed but also expressed, forming the very essence of national, regional and local identities, constituting an integral part of the modern life in Tatarstan, Russia, and characterizing its Outstanding Universal Value. The historical, archaeological and architectural heritage of Bolgar, the established collective memory of the ancestors of the modern Tatar people - the second largest nation in the Russian Federation, the sacrality and successive development of Muslim and Orthodox cultures are indispensable attributes of the Complex, representing the basis for the preservation and development of its territory.

An important defining feature of Bolgar and its culture is the spirit of this place, its character and the qualities of a territory where Islam was adopted. Possessing the main semantic and symbolic meaning, it determined the civilizational choice of the country and its people. The fact, constituting the Outstanding Universal Value of Bolgar, is the exceptional journey made by the Baghdad Caliphate embassy in 922. Having passed more than 2.5 thousand $\mathrm{km}$., they reached Bolgar and left the magnificent records of Ibn Fadlan [Khairutdinov]. As a result, the name of Bolgar and the name of Rus became known through this Arabic document. It led to the official voluntary adoption of Islam by the Bolgarians and the spread of the Islamic faith far north of the centers of Islamic civilization.
Bolgar is the earliest and the most northern Muslim enclave in the world. The very fact of Islam penetrating so far to the north is a world-wide event. At that time, Bolgar, located at an unimaginable distance from the centers of Islamic civilization, became one of the brightest examples of medieval culture of the Muslim Renaissance Era within a short historical period. To date, this fact has determined the nature of faith, customs, traditions, social and moral standards, and culture and spirituality in general in this geocultural region [Khairutdinov].

The embassy of the Baghdad caliphate, which is known in the world history under the name of Ibn Fadlan, promoted not only the official adoption of Islam, but also the diplomatic recognition of Volga Bolgaria as a Muslim state. [Valeev]. For millennia, the ethno-confessional situation rapidly changed in the Volga-Ural region determining its originality, which manifested itself in all areas of life - economy, culture, science, education, and spiritual life. The travel notes, compiled by Ibn Fadlan, are a masterpiece of medieval Muslim literature, written in the Risale genre and found in numerous publications in Tatar, Russian, German, French, English and other languages, in the works of art, in world cinema, and other fields of culture [Khairutdinov].

The unique originality of the Bolgar cultural heritage is based on fruitful mutual influence of local, Turkic, Eastern, European, and Russian traditions. These stylistic features in the architecture of the Bolgar Historical and Archaeological Complex interacted with each other reflecting their diverse influence over a long period of time [Valeev].

The monuments of Bolgar are a clear example of the creative and fruitful use of various building traditions, which Bolgar architects successfully adapted to local conditions. Their ideas, embodied in stone - the buildings of mosques, minarets, mausoleums and baths, not only determined the appearance of Bolgar, but also significantly influenced the urban planning culture of the Kazan Khanate, and later the Russian state [Khairutdinov].

The Bolgar Historical and Archaeological Complex is the northernmost monument of Muslim architecture in the world and the only Complex with preserved architectural and archaeological monuments of the Golden Horde civilization. The Cathedral Mosque, the Eastern and Northern Mausoleums, the Khan's Tomb, the Minor Minaret, the Black and White Chambers, the Khan's Palace these and other archaeological monuments are 
Bolgar's gems, a visible confirmation of the uniqueness of the city's medieval life, expressed both by the diversity of architecture and by the original planning of urban space [Valeev].

\section{Criterion Two}

The Bolgar Historical and Archaeological Complex is unique evidence of the historical continuity and cultural diversity, developed on the territory of the Volga-Ural cultural region during the period of the Volga Bolgar ancient civilization the historical Bolgar state, the Golden Horde of the $10^{\text {th }}-15^{\text {th }}$ centuries, and the multicultural space of Eurasia in the $10^{\text {th }}-21^{\text {st }}$ centuries as a whole. The prominent position and importance of the Bolgar settlement in world history fully complies with Criterion Two.

Medieval Bolgar was distinguished by the diversity of its population. Bolgars, Rus, FinnoUgrians, representatives of the Kushnarenkovsky (ancient Magyars), Petrogromic, post-Petrogromic and Chiyalik archaeological cultures, Mordovians, Mari, Udmurts, Alans, Oguzes, Kipchaks, Mongols, Tatars, Russians and Armenians lived here. This amazing ethnic diversity is noted in many sources of that time. Accordingly, well-preserved was the prayer of foreign Rus merchants, beautifully described by Ibn Fadlan, and the rite of one of their leader's funeral that especially struck him. Excavated at the end of the $19^{\text {th }}$ century, the mounds near the village of Balimers, not far from Bolgar, are associated with these events.

The city was visited by numerous Muslim merchants from the countries of the East - Merv, Nishapur, Khorezm, etc., Ancient Russia and Russian principalities, artisans - even tailors from Baghdad, India, steppe nomads, and representatives of northern peoples were among them. And each of them found something to meet their trade and economic interests in this hospitable and welcoming city: furs and coins, jewelry and leather products, and many other goods. The active development of Bolgar made it a major international trading center, connecting West and East, North and South. It used to be the key center on the northern part of the Great Silk Road, later, in the 15 th century, this function was successively transferred to Kazan (Bolgar al-Jadid, Gostiny Ostrov), then, in the $16^{\text {th }}$ century, it was passed over to the Moscow kingdom.

A variety of artifacts and material evidence of those times show that, intensive ethnocultural processes took place in these historical territories in the $11^{\text {th }}-15^{\text {th }}$ centuries, both forming a layer of "syncretic material culture" common to all partici- pants in the events and giving rise to the appearance of mixed groups of a new population. All this contributed to the development of a unique cultural diversity, which was a special distinguishing feature of Bolgar. It was the most significant urban center of Volga Bolgaria in pre-Mongol time, the capital center of the Volga Bolgar's state in the $10^{\text {th }}-11^{\text {th }}$ centuries, and in the $13^{\text {th }}$ century, it became the first capital of the Golden Horde.

By the $14^{\text {th }}$ century, active Islamization and Christianization of the urban, sedentary, and later nomadic population of this region had secured qualitatively new principles of its social structure. Bolgar was a kind of "a melting pot" where original and advanced elements of various sociocultural systems were formed, gradually creating the basis for the development of the unusually diverse culture of the city. This is an outstanding example of the urban spatial organization and advanced urbanism in Volga Bolgaria and the Golden Horde. It testifies to the existence of the Bolgar-Tatar civilization and the center of cultural exchange between the nomadic civilizations of Asia, Europe and the Middle East.

Bolgar is a unique example of Muslim and Christian religious interactions. Against the background of inter-religious conflicts and clashes that overwhelmed the entire medieval history of Europe and Asia, adherents of various faiths lived peacefully in Bolgaria. Numerous archaeological artifacts and information from written sources convincingly confirm the residence of the Russian population, the existence of the Armenian cemetery, the Christian church, known as the Greek Chamber, and other non-Muslim monuments in Bolgar. This unique tradition of the interfaith world, which originated in Ancient Bolgar, actively manifested itself in the future - during the period of the Golden Horde and the Kazan Khanate. In modern Tatarstan, it is the most important factor, influencing the progressive and dynamic development of the republic.

Epochs succeeded each other, but the paradigms of culture and spiritual life that had been formed in Bolgar determined the traditions and moral standards in the Volga and Ural regions for many centuries ahead, laying the foundation for the modern Tatar ethnic group and other numerous peoples of this region.

Over the centuries, Bolgar had a diverse impact on the development of many areas of life in Eastern Europe and Eurasia as a whole. This city is an outstanding example of a surprisingly good organization of urban economy, the reason and condition 
for the active urban development in the region, which undoubtedly puts it on a par with the most developed cities of medieval Europe.

Formed under the conditions of the Bolgar and Tatar civilization project, its culture and spiritual life determined the values and customs, the nature of the heritage, as well as the rules and laws of life in the region. Although transformed and modified in the era of the Golden Horde and the Kazan Khanate, and during the time of the Moscow Kingdom, the Russian Empire, and the Soviet Union, they were preserved in the traditional culture of the Tatar people, studied and interpreted in the professional sphere. Currently, the Bolgar Historical and Archaeological Complex is the only genuine tangible trace of the Volga Bolgaria's existence and the existence of the Golden Horde during its heyday.

Occupying an extremely important region of Eurasia, located at the intersection of trade, economic, cultural, and political communications, Bolgar became a necessary transmission link in civilizational contacts between East and West, North and South settled and nomadic cultures, between the worlds of the Forest and the Steppe. The result of these processes was the creation of a unique traditional culture, affecting the development of economy, technology, urban planning, architecture, monumental and applied arts, and spiritual culture of the region.

The Bolgar Historical and Archaeological Complex has become a vivid and unique expression of cultural interactions and mutual influence, which resulted in the creation of the distinctive and unique character of Volga Bolgaria and the Golden Horde culture. For over ten centuries, it has been a visible embodiment of urban planning, cultural and landscape-transforming activities, and their subsequent interpretation in the area of spiritual culture, folklore, and scientific knowledge.

For the Volga-Ural region, the result of these processes, which originated in the culture of the historical Bolgar state, is the current ongoing exchange of values, generated by intercultural, interregional and interethnic contacts, significantly enriching the culture of the region and world culture as a whole.

The Complex is characterized by such features as universality, integrity, authenticity and mutual influence of cultures found not only at material, architectural, everyday life, and stylistic levels, in arts and crafts, but also in the spiritual sphere and intangible heritage - ideology, language, writing and literature, folklore, in the unity of ideas, symbols, norms, and images.

\section{Criterion Six}

The diversity of continuous centuries-old cultural, spiritual and sacral life in the historical territories of the Bolgar Complex and in the region is confirmed by numerous unique data. The factors, determining the role of the Complex as an outstanding center related to events, traditions, ideas and works that meet Criterion Six and fully reveal the Outstanding Universal Value of Bolgar, are the following:

Since the official adoption of Islam by the Volga Bolgarians in 922, Bolgar has remained a sacral place for many centuries, and its monuments have been the objects of religious worship of Muslims not only in Tatarstan, but also in Russia. This place has a special spiritual aura, which is the intangible heritage of the highest level. For the multimillion Tatar people, Bolgar personifies spiritual unity, their ancient political and religious capital.

Active trade and economic contacts of the Volga-Ural region, the countries of Central Asia Khorezm and the state of the Samanids, created favorable opportunities for Muslim preachers' penetration into this territory and for the emergence of a stable ummah. Ibn Ruste, an author of the early $10^{\text {th }}$ century (903), writes about the presence of mosques and madrassas in the Bolgar settlements. At the headquarters of the Bolgar ruler Almush, who adopted the Muslim name of Jafar ibn Abdullah, there was a special clergy staff, including a muezzin. The embassy of the Baghdad Caliphate, which entered the world history under the name of Ibn Fadlan, contributed to the official adoption of Islam and the diplomatic recognition of Bolgaria as a Muslim state. It is not only in Eastern, but also in Russian and West European sources, that the name of the Volga Bolgars, and later the Tatars, was strongly associated with the notion of "Islam".

The adoption of Islam led to the replacement of the Bolgarians' ancient Türkic runic writing by the Arabic script. Under those conditions, the transition of Bolgaria to the Arabic script was preferable, as it opened up wide opportunities for Bolgar science and culture to rise to the international level. Bolgaria actively developed international economic and cultural relations, primarily with the countries of the Muslim East. Gradually, the Arabic language, along with Bolgarian, became the language of Bolgar science and diplomatic correspondence, while Farsi (Persian), along with Volga Turki, became the language of Bolgar poetry [Valeev, pp. 461-468].

The strengthening trade and economic ties with the countries of the East enhanced the spread of 
Arabic writing in the Bolgar education system. In Volga Bolgaria and the Golden Horde, the main material for writing was paper imported from distant China and Samarkand. They used parchment less frequently than Western nations. This explains the poor preservation state of written monuments of the Old Bolgar and Golden Horde periods. Islam gave new impetus to the accelerated development of Bolgar science and culture. At the turn of the $11^{\text {th }}$ and $12^{\text {th }}$ centuries, there lived a scientist in Bolgaria - historian, chief judge Yakub ibn Nugman - the author of the book "History of Bolgaria", which was highly appreciated by an Arab traveler from Spain, geographer Abu Hamid al Garnati (al Andalusi), who visited the great city in 1135.

The Bolgarian-Tatar enlightenment was so highly respected and recognized that in the $11^{\text {th }}$ century, scholar Khoja Ahmed Bolgari was appointed a teacher and mentor of one of the most powerful monarchs in the world, Sultan Mahmud Ghaznevi. No wonder, Bolgaria was called the "kingdom of reason" and the "golden throne of the East". Having moved from Bolgar to Afghanistan, Khoja Ahmed Bolgari worked as a doctor in the city of Ghazni. He became famous for his philosophical and historical treatises. Among them, the most well-known were "Tarihatel Bolgaria" ("The History of Bolgaria"), "Fanandel Bolgaria" ("Science in Bolgaria"), and "Zhemigyl Bolgaria" ("Philosophy of Bolgaria"). In 1971, a mausoleum (Dürbe) of white marble was built over his grave.

The high level of Muslim urban culture promoted the active work of other educators, teachers, and scientists. In the late $11^{\text {th }}$ early $12^{\text {th }}$ centuries, here lived and worked Hamid bin Idrisi alBulgaria, in the early $12^{\text {th }}$ century, historian Yakub bin Nugman al-Bulgaria, theologian Suleiman bin Dawood al-Saksini (the $11^{\text {th }}-12^{\text {th }}$ centuries), pharmacologists Khoja al-Bulgaria (the $11^{\text {th }}-12^{\text {th }}$ centuries), as well as brothers Tadzhdin and Hassan bin Yunis (the $13^{\text {th }}$ century). In the first half of the $14^{\text {th }}$ century, here lived the famous lawyer Burhan ad-din Ibrahim al-Hanafi, the author of the book "Basics of Discussions" [Valeev, Sitdikov, Khairutdinov].

Numerous Islamic educational institutions carried the light of knowledge in Great Bolgar: famous theologians and philosophers preached in mosques, thinkers wrote scientific treatises, and poets created their wonderful works. Even today, Bolgar scientists' works in medicine, astronomy, mathematics, and other sciences are known far beyond the borders of Russia. We also know about major religious projects. Thus, Beykhaki (the $11^{\text {th }}$ century) reports that in 415 hijra (1024/1025), the ruler of Bolgar sent money to the Nishapur region for the construction of two mosques in Sebzevar and Khosrovjerd and "amazing gifts" for sovereign Khorasan. There exists a lot of information about the travel patterns of religious Sufi preachers, indications of the origin of a number of prominent theologians, jurists, and doctors who gained recognition throughout the Muslim world. Trade and diplomatic contacts with the countries of the East were regular and stable. [Izmailov]

The Tatar people's historical memory has preserved the legend telling about the arrival of the Prophet Muhammad's three associates in Bolgar, about the miraculous healing of the Bolgar King's daughter, Tuybike, and about the adoption of Islam by the Bolgar king and his entourage. As the old Bolgar manuscript states and as was retold in the $19^{\text {th }}$ century by Karl Fuchs, the rector of Kazan University, a scientist and doctor, an honorary citizen of Kazan, and a German by birth, it all began in the $9^{\text {th }}$ year of the Hijra, when the Prophet Muhammad sent his Sahābah, (Companions) to the peoples and states of the world to spread Islam. Three such sahabahs of the Prophet, Imams AbdurRahman - the son of Zubayr, Talha ibn Gusman, Zubayra - the son of Jagd, (in your last booklet Abdrahman ibn Zubayr, Talha ibn Gusman, Zubayr ibn Jagd) arrived in Bolgar with the mission of da'wah (a call to adopt Islam). The details of their mission among the Bolgars were described by Karl Fuchs. Until the second half of the $18^{\text {th }}$ century, in Bolgar, there had been graves of the Prophet's Companion and his thirty three "Tabigins" (people who adopted Islam through Companions) [Valeev].

Muslim burial grounds and funeral rites are vivid evidence of the spread of Islam. In the VolgaUral region, more than 80 soil burial sites have currently been investigated, of which 52 belong to the pre-Mongol period (the $10^{\text {th }}-13^{\text {th }}$ centuries), and the rest date back to the Golden Horde times. Muslim funeral rites became dominant from the turn of the $10^{\text {th }}-11^{\text {th }}$ centuries and until the middle of the $13^{\text {th }}$ century taking on uniform "canonical" forms.

In the Golden Horde period, religious practices changed and brought about the changes in funeral rites: stone epigraphic monuments and construction of the Dürbe mausoleums. In the early $1840 \mathrm{~s}$, the famous Russian orientalist I. N. Berezin studied inscriptions on the medieval epigraphic monuments, preserved on the territory of the ancient settlement. The interpretation and analysis of the in- 
scriptions were first published in his book "Bolgar on the Volga".

Since the $15^{\text {th }}$ century, Bolgar has been a center of religious worship and pilgrimage to these holy places. The Russian Empress Catherine II used figurative language to describe this place and events, first in her letter to Count N. I. Panin, then to the great French philosopher-enlightener Voltaire. In 1767, on her way from Kazan to Simbirsk, she visited Bolgar and wrote that "the Tatars have great respect for this place and come to these ruins to pray to God". In 1838, prominent Russian artists, brothers G. and N. Chernetsov, when visiting Bolgar, noted: " $<\ldots>$ the place where $<\ldots>$ their Prophets were buried; the Tatars venerate them as saints and come from distant places to worship them $<\ldots>$ from Ufa, Orenburg, Kazan, $<\ldots>$ Bukhara, and $\langle\ldots>$ Khiva. Among the worshipers, Bolgar residents saw blacks (blackamoors): they were here for two or more days, sometimes bringing along mullahs on purpose to perform their religious rites".

Bolgar and its territory vividly illustrate the development of Islam, its institutions, dogmatics, law schools-madhhabs, the stages of its evolution as a part of Volga Bulgaria, the Golden Horde, the Kazan Khanate, the Russian state, the specifics of the Russian Muslim community development and the nature of their relations with the state. This object is of great spiritual and religious value being the embodiment of a whole range of intangible values that directly indicate the Outstanding Universal Value of the Complex. Even today, on the territory of the White Mosque, and on Muslim holidays - in the Cathedral Mosque, a prayer is read at the Minor Minaret and the Khan's Tomb, preserving the unchanging traditions of spirituality and holiness of the place. The White Mosque and the Memorial Sign have become symbols of reviving spirituality after many years of atheism and totalitarianism, the place of Muslim rites and rituals.

The educational activities of the Islamic Center, currently established in the White Mosque, ensure the preservation of traditions, the principles of instruction and learning, thereby increasing the significance of this Complex. Its Outstanding Universal Value includes such value aspects as spirituality, the pilgrimage to shrines, the performance of rituals and holiness, and quite a number of historical events (the adoption of Islam in 922 and the arrival of the Embassy of Ibn Fadlan, it being the capital city, etc.) [Valeev, Sitdikov, Khairutdinov].

The Cathedral Mosque with the Great Minaret (the $13^{\text {th }}-15^{\text {th }}$ centuries) and the Assumption
Church (the $18^{\text {th }}$ century) located nearby are a testament, an indicator of tolerance and peaceful coexistence of the Muslim and Christian religions. Bolgar, as a vivid example of the Islam development in the region, confirms the centuries-old traditions of interfaith tolerance, good neighborliness and mutual respect of the Volga-Ural peoples and the Russian Federation. Under the conditions of a multiconfessional and multicultural society, the traditions of Russian Islam with its centuries-old coexistence with Orthodoxy and other religions received new impetus.

Since the time of the Kazan Khanate, Bolgar has acquired the importance of an outstanding cult and spiritual center, a sacred place of worshipping ancient buildings, which have been preserved in Bolgar-Tatar oral folk traditions as monuments of Islam and Bolgarian-Tatar statehood for many years. The vivid pictures of Bolgar's urban life are found in brilliant samples of medieval BolgarTatar literature: Kul Gali's poem "Kyissa-iYusuf", its $800^{\text {th }}$ anniversary was celebrated by UNESCO, and in the epic "Idegei", in folk legends and traditions. In their works, Tatar poets Muhammedyar (the $16^{\text {th }}$ century) and Movly-Koly (the $17^{\text {th }}$ century) repeatedly turned to the heroic and lyrical image of Bolgar. Bolgar became a real source of creative inspiration for Tatar enlighteners and the founder of Tatar historical science Sh. Mardzhani [Valeev].

The Tatar people have always remembered, known and glorified the city of Bolgar - "Shekhri Bolgar" - in their historical bayts, legends, munajatis, calling it the place of saints "izgeler zhire". During the time of the Kazan Khanate, and even in later times, a Tatar settlement was located near Bolgar, its inhabitants were charged with the duty of preserving the Dürbe mausoleums and other outstanding monuments.

The influence of Bolgar on the minds of many generations of the Tatars was so great that the custom of adding "al-Bolgari" to the nisbu name remained among the Tatar intelligentsia until the beginning of the $20^{\text {th }}$ century. The living connection of the Tatar people with Bolgar has not interrupted for centuries. Up to now, the Kazan Tatars' traditional culture has preserved incomparable motifs of Bolgar ornaments, its traditions of housekeeping and home culture.

The unique historical, cultural, and spiritual aura of Bolgar has always attracted prominent travelers, writers, poets, scientists, artists, local historians, architects, and restorers. Among them are poet Kul-Gali, Khans Batu and Berke, Emperor Peter I, 
Empress Catherine II, the prominent Russian artists I. I. Shishkin, A. K. Savrasov, brothers N. G. and G. G. Chernetsovs and many others, those who left valuable evidence, descriptions, drawings, sketches, floor plans of buildings and ruins of the ancient city.

The existence of Bolgar settlement in the $10^{\text {th }}$ $15^{\text {th }}$ centuries and the settlement of the $15^{\text {th }}-16^{\text {th }}$ centuries, located in the same place, is confirmed by archaeological objects and artifacts against the background of successive historical eras (the period, preceding the construction of the city, the time of pre-Mongol Volga Bulgaria, the Golden Horde, the Kazan Khanate). Enshrined in the monuments of intangible culture as folk legends and traditions in the 17 th $-19^{\text {th }}$ centuries and existing at present as a fact of worship and preservation, the ruins of Bolgar architectural monuments (the Orthodox monastery and the Assumption Church in the $18^{\text {th }}$ century) are sufficient evidence of a stable unified historical and cultural tradition, presenting the original nature of Bolgar as an outstanding cultural region of the world, which has exerted a sustainable impact on the development of culture and arts, architecture and urban planning for fifteen or more centuries.

The spiritual heritage of Bolgar, the vivid and rich history of the capital of Volga Bolgaria and the Golden Horde gave powerful impetus to the development of Tatar art, theater and music, fiction and poetry, national culture as a whole. In recent years, the cultural heritage of Bolgar has inspired the creation of new outstanding samples of national culture. Among the most interesting works are: the poem "The Oath Cup" (2005), the ballet "The Legend of Yusuf" (2001), the ballet "The Golden Horde" (2013), the opera "The Black Chamber" (2013), etc. The historical novels by Nurikhan Fattakh, Musagit Khabibullin, Roman Vakhitov and many other Tatar writers, the works by artists Baki Urmanche, Ravil Zagidullin, Kanafi Nafikov, Rifkat Vakhitov, Ferinad Khalikov and others have received national recognition [Gorod Bolgar, 1996], [Gorod Bolgar, 2001], [Gorod Bolgar, 2008].

Even today and for many centuries, Bolgar has been one of the main centers of pilgrimage for Muslims of Russia and the Tatar diaspora around the world. Bolgar has acquired the importance of an inter-regional cultural center of Russian Muslims, becoming a unique platform for international cooperation and the only museum-reserve which represents the history of Islam in the Russian Federation and Muslim culture as part of Eurasian civilization. The White Mosque and the Memorial
Sign, erected here, are excellent preservation symbols of the continuity of Bolgar centuries-old spiritual traditions.

\section{INTEGRITY AND AUTHENTICITY OF THE COMPLEX}

The Outstanding Universal Value of this historical territory and its Criteria is fully confirmed by its integrity and authenticity, conveyed by its characteristic features and unique values.

\section{Integrity}

Within the boundaries of the monument there is a large territory with the elements sufficient to present its evolution course and results, emerging during the life of various ethnic groups in Bolgar and the region in the $15^{\text {th }}-21^{\text {st }}$ centuries.

The Bolgar Historical and Archaeological Complex, as a valuable and unique evidence of the existence of Volga Bulgaria and the Golden Horde, has no analogues in the world. Systematic studies, continuously carried out here for almost 150 years, make it possible to reconstruct in detail the diversity of life in the ancient city and its environs.

The results of these studies enabled the researchers to obtain detailed information on 30 brick-stone structures, 16 of which are used for conservation and museumification for tourist displays. The remaining facilities have been conserved. Architectural and archaeological information on these monuments has been preserved in the form of detailed scientific reports. All these data have been an inexhaustible source for researchers in their scientific studies, which, in their turn, became the basis for developing the Program of the Bolgar Monuments Museumification until 2019.

Ninety seven per cent of the Complex has not been affected by archaeological research, forming an integral cultural layer of the monument. Modern archaeological research is carried out by using predominantly non-destructive methods, thus meeting international standards.

Bolgar is evidence of the formation and development of the unique practice of state and public forms, used to protect historical and cultural monuments in the country and in the world. The influence of the Bolgar-Tatar civilization on the Eurasian people's history and development was so significant that for the first time in the history of Russia, in 1722, Emperor Peter I adopted a decree on the preservation and restoration of the Great Minaret of the Cathedral Mosque at the state level. It was from this time that the state began protecting antiquities in Russia and initiated the conservation and restoration work on the monuments of the ancient city. 
The uniqueness of the Bolgar Complex was unconditionally recognized by scientists and the general public, the fact confirmed by the first project in the Russian history of the museum business, aiming to create an archaeological museum-reserve on the territory of the monument in the mid-1850s. Since the second half of the $19^{\text {th }}$ century, there existed and actively worked state and public institutions, ensuring the conservation and study of Bolgar's monuments. Since 1969, the objects of the Complex have been united by the Historical and Architectural Museum-Reserve. The status of a monument of federal significance, protected by the state, has made it possible to preserve in good condition all the architectural objects and cultural archaeological layers, associated with the medieval life of the city.

The Bolgar settlement is a valuable and inexhaustible source for replenishing knowledge about the brilliant history and culture of the Bolgar-Tatar civilization. For 300 years, a unique methodology for studying the monuments of the Complex has been developed on this territory. An outstanding fact is the beginning of systematic archaeological research on the object from the middle of the $19^{\text {th }}$ century, which laid the foundation for "Bolgar Studies" as an independent scientific trend in archeology in the early $20^{\text {th }}$ century.

The objects, recovered during excavations, are subject to comprehensive restoration. For newly identified archaeological and architectural objects, the applied conservation methods take into account the state of the object and the specifics of its location on the site. The conservation of new objects is carried out by creating combinations of structures on the surface without their physical connection with the original ("two-dimensional conservation"), thereby expanding opportunities for tourists and pilgrims. In this way conditions were created for implementing a strategy aimed to maintain archaeological integrity, a careful approach to excavations, and the integrity of the Complex territory in order to prevent the possibility of reducing its authenticity.

\section{Authenticity.}

The preserved ramparts and moats up to $5 \mathrm{~m}$ high, running over the entire length of the territory, are a defining and significant attribute of the Complex. They vividly demonstrate the integrity and authenticity of the Complex and allow one to visualize and reveal the object within the historical boundaries of its fortifications, dating back to the $14^{\text {th }}$ century. Based on Criteria II and VI, and the analysis and characterization of the Complex val- ues, its authenticity is well revealed against the broad context of Eurasia's historical period of 1,500 years.

Over this period of time, the territory of the Complex was a unique intersection center of successive chronological and spatial characteristics of material, spiritual, and architectural values, displaying the features of cultural landscapes and technologies of the Finno-Ugric, Bolgarian, Tatar, Slavic and other socio-cultural communities of Muslim and Orthodox faiths and cultures, various eras of reign and states, interactions and mutual influences in the urban, architectural and other cultural and artistic self-expression. The integration, synthesis and mutual influences of historical, cultural and religious values are expressed in the authenticity of the cultural landscape, historical topography, its cultural layer, the rampart and moat, its archaeological materials and architectural monuments, reflecting the 1500-year history of the territory.

Even before the Bolgars, the fortifications, built by the population of the Imenkovsky culture (the $5^{\text {th }}-7^{\text {th }}$ centuries), had already existed on the Koptelov Hill. In the $10^{\text {th }}$ century, the fortress was greatly expanded by the Bolgars. Along the inner moat, Bolgar was surrounded by a wooden wall. Simultaneously with the creation of fortifications, people settled on a vast territory in its immediate vicinity.

By the $11^{\text {th }}$ century, Bolgar Craft Posad had expanded its territory with iron-making, copper processing, leather, and other industries. Thus, a medieval feudal city gradually came into being. Numerous villages were scattered along the wide and extremely picturesque Volga terrace. On the very bank of the Volga, the eastern bazaar did a roaring trade - the Aga-Bazar-Torgische, which was mentioned in written sources in the early $10^{\text {th }}$ century. Subsequently, the active development of Bolgar as an international trading point was successively transferred to Kazan in the $15^{\text {th }}$ century, to Nizhny Novgorod in the $16^{\text {th }}$ century and later to Moscow.

In the $11^{\text {th }}-$ early $12^{\text {th }}$ century, Craft Posad actively developed; on the outskirts of the city, ironsmelting workshops with syrodutnyh furnaces appeared. By the end of the pre-Mongol period, the area of Posad had been already three times the area of the original city. It was by this time that the nearest southern suburban village had been included in the territory of the city. The population of the city was growing rapidly with widely developed residential construction. 
Until the end of the pre-Mongol period, the city's Posad was not fortified, only in the late $12^{\text {th }}$ - early $13^{\text {th }}$ centuries, a defense system was created that surrounded the more densely built-up part. The second half of the $13^{\text {th }}-$ early $14^{\text {th }}$ centuries is the time of Bolgar's restoration and prosperity. As the old economic center of the Volga region, it became the main city of the $13^{\text {th }}$ century Golden Horde khans. The early days of the Golden Horde was the time when the borders of the city were expanded, its craft production was restored and increased, its trade ties were strengthened, and monumental construction began.

By 1330, the architectural ensemble of Bolgar center had been completed, the Cathedral Mosque with the Big Minaret became its real gem. The city's public center was decorated with other unique architectural structures - the Khan's Palace, the Eastern and Northern Mausoleums, also known as the "Church of St. Nicholas" and the "Monastery Cellar". According to the masonry material, technical and decorative techniques, the Bolgar Cathedral Mosque with the Great Minaret has similar features to the stone buildings of Transcaucasia, Crimea, Asia Minor, and Northern Mesopotamia. At the same time, the architecture of this unique monument has volumetric and compositional features inherent in the buildings of Central Asia of the Golden Horde period, as well as local traditional methods, used in the construction of the Cathedral Mosque in Bilyar and the mosque fortress in Yelabuga. At present, the appearance of the central part of the Complex corresponds to the iconographic documents of the $18^{\text {th }}-19^{\text {th }}$ centuries. For tourists and pilgrims the observation deck of the minaret is accessible. From its top, one can get a beautiful view of the Bolgar fortification and its architectural monuments, the vast expanse of the Volga and amazingly picturesque meadows and green copses.

The Black Chamber, an important element of the existing city public center, is another building dating back to this time. Built in the $14^{\text {th }}$ century, the construction of white limestone, whose structure and artistic interpretation is very close Central Asian architecture, is the only surviving civil structure of this period. The exact purpose of the Black Chamber has not been established, presumably it used to be a court house, a madrasah, or a hospice (khanaka).

All the monumental buildings of ancient Bolgar have their own, distinctive originality. Having mastered and put to practice the traditions of Islamic architecture of the Arab Caliphate, Bukha- ra, Khorezm, Derbent, as well as the architecture of the Khazar Kaganate, the State of the Seljukids, Byzantium, Armenia, India and the rich cultural heritage of pre-Islamic pagan cultures that they had inherited, local architects developed their own aesthetic concepts, peculiar techniques and methods taking into account local climatic conditions. A peculiar floral architectural decor was developed, based on local building materials, pre-Islamic and Islamic spiritual traditions and influences.

The stone buildings of mosques, minarets, mausoleums, and bath houses both determined the appearance of the city of Bolgar in the $13^{\text {th }}-15^{\text {th }}$ centuries and influenced the architecture of the Kazan Khanate, whose traditions had a continuous development in the era of its accession to Russia. Even after life in the city of Bolgar died out, the memory of its architecture was preserved in Tatar folk traditions, the Türkic-Tatar epic "Idegei", and the ruins of its buildings, which together with the surrounding landscape, became a place of religious worship, aesthetic admiration, and later the focus of scientific research.

To the south-west of Bolgar's public center there used to be a trading courtyard where jewelry glass was made. At that time, the city baths were located in the piedmont and riverine parts, along the banks of the river Melenka. To date, the remains of six Bolgar public baths have been fully studied. Having many common design features, they nevertheless differ in location, size, planning features, material, and time of construction. Bolgar's baths have similar features with typical oriental hammams.

Rich brick houses with underfloor heating systems were situated in the southeastern areas of Bolgar, this was where the city nobility lived. After 1361, urban cemeteries and places of worship appeared in most of this territory - a complex of tombs and the Minor Minaret. A number of necropolises can be observed in the southern areas of the city. In general, among the monumental stone buildings of the Bolgar Historical and Archaeological Complex, a special place belongs to ritual structures - mausoleums - Dürbe. In addition to the Eastern and Northern mausoleums, and the Khan's tomb, there are nine more mausoleums in the Complex. They are preserved at the level of foundations, and four mausoleums are hidden under the hills. Bolgar's mausoleums were built of limestone in the middle of the $14^{\text {th }}-$ early $15^{\text {th }}$ centuries. They contain burials, which, as investigation indicates, are Muslim burials of noble and especially revered persons. 
In the western and northwestern regions of Bolgar, numerous crafts functioned - metallurgical, pottery, jewelry, and copper foundry. The area of Galan Lake was distinguished by a large concentration of production complexes; archaeologists discovered large deposits of gray clay on its banks. The numerous fragments of Bolgar dishes and ceramic forges found here make it possible to assume that mass pottery production was concentrated in this place during the heyday of the city in the middle of the $14^{\text {th }}$ century.

To the south of the fortification, behind the rampart, was the Small Town, fortified with moats and ramparts, its front entrance decorated with stone pylons from the north side and a stone building in the southern part. The name "the Small Town" was first recorded in Clerk Mikhailov's inventory in 1712. It is believed that these are the remains of an unfinished front complex or caravanserai. There is also an assumption of his cult function.

In the northwestern part, the Armenian settlement adjoined the city, it had replaced a suburban village of Bolgar. Here, archaeologists have identified wooden dwellings and a series of burials. The materials obtained indicate the existence of the Christian colony and cemetery in the $14^{\text {th }}$ century. There are also the remains of a stone religious building, called the "Greek Chamber", which are the ruins of a Christian church possibly built as a prototype of the Church of the Holy Virgin (Surb Astvatsatsin) in Noravank Monastery (Armenia).

The interactions of Muslim and Christian religions are clear evidence of the mutual influence of religious values in Bolgar. Besides, there are a significant number of archaeological artifacts associated with these beliefs and the Russian population living in Bolgar, a separate cemetery possessing tombstones with inscriptions in Armenian, archaeological remains of the Christian church - the Greek Chamber, and other visible material objects. Multiculturalism, which became an integral part of the spiritual life in the Bolgarian state and the Golden Horde, actively manifested itself during the period of the Kazan Khanate and the Russian state.

The uniqueness and universal value of the Bolgar Complex territories is characterized by the continuity of historical and cultural traditions that have been preserved here for many centuries. The early development stages of this region are confirmed by numerous data from studies conducted by researchers of the Babi Bugor burial ground and Bulgarian villages, dating from the $5^{\text {th }}-7^{\text {th }}$ centuries A.D. The development of this region contin- ued even in later historical periods after the Bulgarian state, the Golden Horde and the Kazan Khanate had disappeared from the political map. The village of Bolgary, which came into being as a monastic settlement of the Assumption Monastery at the beginning of the $18^{\text {th }}$ century, exists in its original borders to this day. Its architectural stylistics and characteristic traits of its inhabitants' lifestyle undoubtedly mirror the centuries-old historical and cultural features of this territory.

The cultural landscape of the Bolgar Complex has remained unchanged over the millennium. Since pre-Mongol times, there has existed a Jerusalem ravine. It represents the most important detail of Bolgar's historical environment, and, at the same time, it is the site of the oldest settlement of the Imenkovsky culture in its territory. Since ancient times and throughout the existence of the medieval city, the ravine was part of its defense system. The landscape of the Bolgarian settlement has retained its borders to date.

The authenticity of the Complex is emphasized by the duration and continuity of the existence and development of the Bolgar-Tatar tradition in this territory, the active and large-scale urbanization of the region, and the acceleration of civilization processes for a number of Eurasian peoples. The necessary condition for preserving the unique objects of the Middle Ages is the creation of the Historical and Architectural Museum-Reserve as a research, museum and restoration center, aiming to combine the remains of all historical eras and create a mechanism for preserving the authenticity of all the attributes of the Complex.

\section{Management of the Complex.}

Today, the Bulgarian Historical and Archaeological Complex is protected by federal and regional laws and governments. In the MuseumReserve, any kind of work is prohibited with the exception of scientific research and museum activities. The Concept and Management Plan of the Complex until 2019 and its management strategy for 20 years were developed and approved. Its preparation involved extensive consultations with various governmental and non-governmental structures, discussions with members of Parliament, the local community and, the International Interdepartmental Scientific and Methodological Expert Council of the Republican Fund of Historical and Cultural Monuments Revival in the Republic of Tatarstan.

In 2010, a new stage in the history of the Bolgar settlement began with the implementation of the project "Cultural Heritage of Tatarstan: the 
Ancient City of Bolgar and the Ostrov-grad Sviyazhsk", which is coordinated by the Republican Foundation "Vozrozhdeniye". An ambitious task was set to make the Bolgar settlement a historical, cultural, museum, and spiritual-sacral center, visually emphasizing the Outstanding Universal Value of the Complex.

The preservation of the Complex is based on the systemic approach to the identification, study, conservation, and museumification of its monuments. The requirements have been set for a continuous comprehensive preventive examination and maintenance of the monuments. The restoration of Bolgar's monuments is considered to be a forced and exceptional measure, aimed at preserving and revealing their historical values. The museum, the Center for the Study of Bolgar Civilization, and archaeological-restoration activities are based on the knowledge, gained in the research process, and the experience, gained in the course of the preservation of archeological and architectural monuments.

The current research programs, carried out in the territory of the Bolgar Historical and Archaeological Complex, focus on the use of advanced modern technologies and natural science techniques, aerial photography, and processing of satellite data. Modern methods of accurate field fixation have been widely introduced, and new methods for dating cultural deposits, objects, and individual artifacts are being created and put to practice.

In Bolgar, in terms of archaeological resource management, a special role is assigned to the International Center for Archaeological Research at the Institute of Archeology, the Academy of Sciences of the Republic of Tatarstan, created to perform both scientific and social functions. It is becoming a major research and scientificorganizational structure for attracting professionals to study and preserve the archaeological heritage, an important platform for scientific discussions, and independent expert activities of the "Center of Excellence" for wide international cooperation and the implementation of educational projects and programs. Here, all the necessary conditions are created for holding research and practice forums, workshops, and student's practical work. Every year the number of tourists and pilgrims, visiting these protected historical areas, increases significantly. In order to fully preserve the authenticity and integrity of the Bolgar Complex, a special program was adopted, and since 2010, the White Mosque, the Bread Museum, and the Memorial Sign in honor of the adoption of Islam, the Museum of Bolgar Civilization combined with the River
Station and the tourist reception center have been built outside the settlement. This non-standard solution made it possible to significantly ease the burden on architectural and archaeological sites.

An important part of the Bolgar Complex management today is the museumification of its fortification sites and the creation of museums, expositions, and exhibitions of various thematic content. The development strategy of its museum and tourist activities is aimed at a wide representation of Bolgar's historical, cultural and spiritual potential, the diversity of its heritage, the importance of adopting Islam, its development as the historical center of Russian Muslim culture, tolerant coexistence with the Orthodox culture, the intersection of cultures and civilizations. Today, like many centuries ago, Bolgar is shining brightly on the horizon of Bolgar-Tatar history. Its brilliant past, its unique material, cultural, and spiritual values, created here, vividly demonstrate the huge potential of the peoples who, for centuries, have inhabited the banks of the Volga and Kama. In the historical fate of Bolgar, there were periods of prosperity and recovery, replaced by decline, and then revival invariably began again. This largely sacral city never ceased to exist, it never used to be a ghost town. If it was physically destroyed, it continued to live in the hearts of the people, the memory of it was carefully passed on from generation to generation. Today, it is coming to life again, its historical fate is filled with new colors and meanings. It unites people again and enhances a feeling of love for the native land and of pride in its history.

\section{References}

Bolgarskii istoriko-arkheologicheskii kompleks (2016) [Bolgar Historical and Archaeological Complex]. T. 1-2. Kazan. (In Russian)

Gorod Bolgar (1996) [The City of Bolgar]. Remeslo metallurgov, kuznetsov, liteishchikov. 314 p. Kazan. (In Russian)

Gorod Bolgar (2001) [The City of Bolgar]. Monumental'noie stroitel'stvo, arkhitektura, blagoustroistvo. 364 p. Moscow, Nauka. (In Russian)

Gorod Bolgar (2008) [The City of Bolgar]. Kul'tura, iskusstvo, torgovlya. 275 p. Moscow, Nauka. (In Russian)

Izmailov, I. L. (2013). Volzhskaia Bulgaria v IXpervoi treti XIII veka: stanovlenie sotsial'noi, religioznoi $i$ etnopoliticheskoi struktury obshchestva: avtoref. dis. ... dokt. Istor. nauk [Volzhskaya Bolgaria in the $9^{\text {th- }}$ Early $13^{\text {th }}$ Centuries: The Formation of the Social, Religious and Ethno-Political Structure of Society: Doctoral Thesis Abstract]. Kazan, 67 p. (In Russian)

Khairutdinov, R. R. (2014). Vydaiushchaiasia universal'naia tsennost' Bolgarskogo istorikoarkheologicheskogo kompleksa - unikal'nogo ob"ekta 
kul'turnogo i prirodnogo naslediia Respubliki Tatarstan [The Outstanding Universal Value of the Bolgar Historical and Archaeological Complex - a Unique Object of Cultural and Natural Heritage of the Republic of Tatarstan]. Sbornik trudov mezhdunarodnoi nauchnoistoricheskoi konferentsii im. Akademika L. Bliumentrostra. Berlin, Wissenschaftliche Welt, pp. 97-101. (In Russian)

Khlebnikova T. A. (1987). Istoriia arheologicheskogo izucheniia Bolgarskogo gorodishcha. Stratigrafiia. Topografiia [The History of the Archaeological Study of the Bulgarian Settlement. Stratigraphy. Topography]. Gorod Bolgar. Ocherki istorii i kul'tury. Moscow, Nauka, pp. 32-88. (In Russian)

Starostin, P. N. (1987). Predbolgarskie pamiatniki na territorii Bolgarskogo gorodishcha [Protobolgar Monuments on the Territory of the City of Bolgar. Essays on History and Culture]. Gorod Bolgar. Ocherki istorii i kul'tury. Moscow, Nauka, pp. 89-98. (In Russian)

Tizengauzen, V. G. (1873). Drevnosti, najdennye bliz g. Spasska Kazanskoi gubernii [Antiquities, Found near the Town of Spassk, the Kazan Province]. Vol. III. Drevnosti, Tr. MAO. Moscow. (In Russian)

Valeev, R. M. (2016). Bolgar i Sviiazhsk: ikh rol'v kul'turnom raznoobrazii $i$ razvitii nauki Tatarstana [Bolgar and Sviyazhsk: Their Role in the Cultural Diversity and Development of Science in Tatarstan]. Mezhkonfessional'noe vozdeistvie $\mathrm{v}$ prostranstve istorich. pamiati. Pp. 461-468. Kazan, izd. Kaz. Fed.unta. (In Russian)

Valeev, R. M., Sitdikov, A. G., Khairutdinov, R. R. (2016). Bolgar - ob"ekt vsemirnogo naslediia IUNESKO [Bolgar Is a UNESCO World Heritage Site]. T.1. 400 p. Kazan, OOO Glavdizain. (In Russian)

\title{
БОЛГАР КАК ОБЪЕКТ \\ ВСЕМИРНОГО КУЛЬТУРНОГО НАСЛЕДИЯ ЮНЕСКО (К 5О-ЛЕТИЮ СОЗДАНИЯ БОЛГАРСКОГО ГОСУДАРСТВЕННОГО ИСТОРИКО-АРХИТЕКТУРНОГО МУЗЕЯ-ЗАПОВЕДНИКА)
}

\author{
Рафаэль Миргасимович Валеев, \\ Казанский федеральный университет, \\ Россия, 420008, г. Казань, ул. Кремлевская, д. 18, \\ valeev_rm@inbox.ru.
}

\begin{abstract}
Статья посвящается 50-летию Болгарского историко-архитектурного музея-заповедника (1969). В работе систематизирован материал по истории создания первой организации в Татарской АССР, комплексно осуществляющей работу по изучению, сохранению, консервации и реставрации памятников истории и культуры татарского народа. Автор приводит систему представленных учеными РТ доказательств выдающейся универсальной ценности Болгар, что послужило основанием для решения экспертов Комитета Всемирного наследия ЮНЕСКО включить музей-заповедник в число мировых памятников, признанных человечеством.
\end{abstract}

Ключевые слова: Болгар, Выдающаяся универсальная ценность, Критерии, Целостность, Подлинность, Аутентичность, Защита и Управление.

Место города Болгара в истории человеческой цивилизации уникально. Болгарский историко-археологический комплекс является тем центром мирового значения, Выдающаяся Универсальная Ценность которого признана решением 37 сессии Комитета Всемирного культурного и природного наследия ЮНЕСКО (2013 г., Пномпень, Камбоджа). В 2014 году в Катаре на 38-й сессии Комитета этот объект включен в список Всемирного наследия ЮНЕСКО и стал 27 российским и 1002 в этом списке [Валеев].

За более чем 150-летнюю историю археологического изучения Болгарского городища накоплен значительный источниковедческий ма- териал по истории этого геокультурного региона. С 1864 года, когда В. Г. Тизенгаузен произвел первые разведывательные раскопки [Тизенгаузен], начались планомерные исследования, продолжавшиеся в конце XIX - начале XX века, затем - в 1930-40-е гг. под руководством А. П. Смирнова, а также исследования, проводившиеся вплоть до начала XXI века учеными Казани - А. Х. Халиковым, 3. А. Акчуриной, А. М. Ефимовой, Т. А. Хлебниковой, О. С. Хованской, Н. Ф. Калининым, П. Н. Старостиным, Р. Ф. Шарифуллиным (см.: [Хлебникова]), которые позволили представить город Болгар $\mathrm{X}$ начала XV века и предболгарские памятники 
V-VII вв. н. э. [Старостин]. Монографические исследования, осуществленные в 1996, 2001, 2008 гг. [Город Болгар, 1996], [Город Болгар, 2001] [Город Болгар, 2008], позволили проанализировать огромный археологический и историко-культурный материал и наметить направления дальнейших изысканий, а также определить значение Болгара в истории Татарстана, России и мировой истории, его Выдающуюся универсальную ценность [Болгарский историко-археологический комплекс].

Болгарское городище с сохранившимися валами и рвами располагается в Европейской части России на левом берегу Волги в 40 км южнее от места слияния ее с Камой и занимает край коренной волжской террасы, примыкает с востока к современному городу Болгар, административному центру Спасского района Татарстана.

Город Болгар в период своего возникновения размещался на стрелке мыса высокой волжской террасы, был сильно укреплен естественно и искусственно и имел достаточно широкий обзор в сторону Волги. Хорошо выраженные в ландшафте фортификационные сооружения городища представляют собой несколько линий укреплений, которые строились в разное время. Подлинные остатки фортификационных сооружений, опоясывающих город, сохранились и формируют сегодня целостный историко-культурный ландшафт городища. Укрепленная часть города к середине XIV в. достигала значительных размеров, и в настоящее время территория Болгарского историкоархеологического комплекса составляет 443 га.

Важным подтверждением стремления государства сохранить целостность объекта стало расширение границ буферной зоны Комплекса, включение в ее состав ранних поселений, идентифицируемых на первом речном острове, и увеличение ее на север для защиты панорамы через р. Волгу. В настоящее время буферная зона Комплекса составляет 12101 га. Это позволяет не только максимально охватить всю территорию Болгарского городища и прилегающих к ней исторических территорий, все их элементы и ценности, уникальные видовые точки и перспективы, но и в дальнейшем исключить здесь крупное многоэтажное строительство и нарушение исторического визуального восприятия объекта [Хайрутдинов].

\section{Выдающаяся универсальная ценность Комплекса.}

Болгарский комплекс является выдающимся примером геополитических и исторических преобразований Евразии в X - начале XXI века, сыгравших ключевую роль в процессах формирования государств и цивилизаций, распространения мусульманства и православия, взаимодействия обычаев и культурных традиций современного татарского и других народов евразийского континента. На протяжении более пятнадцати веков этот объект оказывал устойчивое воздействие на развитие архитектуры, технологий, монументального и декоративного искусства, градостроительства, сферы духовной культуры Евразии [Валеев].

В Болгаре не только фиксируется, но и выражается длительный процесс исторического развития в X-XXI вв., формируя саму суть национальной, региональной и местной самобытности, являясь неотъемлемой частью современной жизни Татарстана, России, и характеризует ее Выдающуюся Универсальную Ценность. Историко-археологическое и архитектурное наследие Болгара, сложившаяся коллективная память о предках современного татарского народа - второго по численности в Российской Федерации, сакральность и преемственное развитие мусульманской и православной культур представляют основу для сохранения и развития этой территории.

Важной определяющей чертой Болгара, его культуры является дух места, его характер и качества как территории принятия ислама, определившей цивилизационный выбор страны, народа и имеющей главное смысловое и символическое значение. Выдающая Универсальная Ценность Болгара в том, что в 922 г. посольство Багдадского Халифата, пройдя более 2,5 тысяч километров, достигло Болгар, и это путешествие, оставившее великолепные записи Ибн Фадлана, уже само по себе являлось исключительным [Хайрутдинов]. В результате этого стало известно имя «Болгар» и название «Русь» в этом арабском документе, что привело к официальному добровольному принятию ислама болгарами и его распространению на севере, вдали от центров исламской цивилизации. Болгар является самым ранним и северным мусульманским анклавом мира. Сам факт проникновения ислама так далеко на север является событием мирового масштаба. Болгар, находившийся на невообразимом по тем временам расстоянии от центров исламской цивилизации, 
в короткий исторический срок стал одним из ярких образцов средневековой культуры эпохи мусульманского ренессанса. До настоящего времени это определило характер веры, обычаев, традиций, социальных и нравственных норм жизни, в целом культуры и духовности в этом геокультурном регионе [Хайрутдинов].

Посольство Багдадского халифата, вошедшего во Всемирную историю под именем Ибн Фадлана, способствовало не только официальному принятию ислама, но и дипломатическому признанию Волжской Болгарии в качестве мусульманского государства [Валеев]. В регионе Волго-Уралья стремительно изменилась этноконфессиональная ситуация, на тысячелетия определив его своеобразие, которое отразилось на всех сферах жизни - экономике, культуре, науке, образовании, духовной жизни. А путевые записки Ибн Фадлана, составленные им, являются шедевром средневековой мусульманской литературы в жанре «Рисаля», нашедшего свое отражение в многочисленных изданиях на татарском, русском, немецком, французском, английском и др. языках, произведениях искусства, в мировом кинематографе и других сферах культуры [Хайрутдинов].

Уникальное своеобразие культурного наследия Болгара основано на плодотворном взаимовлиянии местных, тюркских, восточных, европейских и русских традиций. Эти стилистические особенности в архитектуре Болгарского историко-археологического комплекса находились во взаимодействии друг с другом и отражают разнообразное влияние на протяжении длительного периода времени [Валеев].

Памятники Болгара являются наглядным примером творческого и плодотворного использования разнообразных строительных традиций, которые были талантливо адаптированы болгарскими архитекторами к местным условиям. Воплощенные в камне их замыслы - здания мечетей, минаретов, мавзолеев и бань - не только определили облик Болгара, но также значительно повлияли на градостроительную культуру Казанского ханства, а в дальнейшем и Российского государства [Хайрутдинов].

Болгарский историко-археологический комплекс - это самый северный в мире памятник мусульманского зодчества и единственный в мире комплекс с сохранившимися архитектурно-археологическими памятниками золотоордынской цивилизации. Соборная мечеть, Восточный и Северный мавзолей, Ханская усыпальница, Малый минарет, Черная и Белая палаты, Ханский дворец - эти и другие археологизированные памятники являются жемчужинами Болгара, представляют собой зримое подтверждение уникальности средневековой жизни города, выраженной не только в разнообразии архитектуры, но и в своеобразном планировании городского пространства [Валеев].

\section{Критерий II.}

Болгарский историко-археологический комплекс является уникальным свидетельством исторической преемственности и культурного разнообразия сложившегося на территории культурного региона Поволжья и Приуралья в условиях существования древней цивилизации Волжской Болгарии - исторического Булгарского государства и Золотой Орды X-XV вв. в целом в поликультурном пространстве Евразии в X-XXI вв. Выдающееся положение и значение Болгарского городища в мировой истории в полной мере соответствуют Критерию II.

Средневековый Болгар отличался разнообразием народов. Здесь проживали болгары, русы, финно-угры, представители кушнаренковской (древние мадьяры), петрогромской, постпетрогромской, чияликской археологических культур, мордвы, марийцев, удмуртов, а также аланы, огузы, кыпчаки, монголы, татары, русские, армяне. Это удивительное этническое многообразие отмечено во многих источниках того времени. Так, сохранилось великолепно описанное Ибн Фадланом моление иноземных купцов-русов и особенно поразивший его обряд похорон одного из их предводителей. С этими событиями связаны раскопанные в конце XIX в. курганы около с. Балымеры, расположенные недалеко от Болгар.

Город посещали многочисленные мусульманские купцы из стран Востока - Мерва, Нишапура, Хорезма и др., Древней Руси и русских княжеств, ремесленники, в их числе были даже портные из Багдада, Индии, кочевникистепняки, представители северных народов. И каждый из них в этом гостеприимном и радушном городе находил свои торгово-экономические интересы: меха и монеты, ювелирные и кожевенные изделия, многие другие товары. Активное развитие Болгара как крупного международного торгового пункта, соединившего Запад и Восток, Север и Юг, являвшегося ключевым центром на северном отрезке Великого Шелкового пути, преемственно перешло в XV в. к Казани (Болгар аль-Джадид, Гостиный остров), затем в XVI в. перешло в Московское царство. 
Разнообразные артефакты и свидетельства того времени показывают, что в IX-XV вв. на этих исторических территориях происходили бурные этнокультурные процессы, где, с одной стороны, формировался пласт «синкретичной материальной культуры», общей для всех участников событий, а с другой - появились смешанные группы нового населения. Все это способствовало развитию уникального культурного разнообразия, который был отличительной чертой Болгара. Это наиболее значимый городской центр Волжской Болгарии в домонгольское время, в X-XI вв. - столичный центр государства волжских болгар, а в XIII веке - первая столица Золотой Орды.

Активные процессы исламизации и христианизации городского, оседлого, а несколько позже и кочевого населения этого края к XIV в. закрепили качественно новые принципы общественного устройства. Болгар был своего рода «плавильным котлом», в котором формировались своеобразные и передовые для того времени элементы различных социокультурных систем, которые постепенно стали основой для развития необычайно многообразной культуры города. Это выдающийся образец пространственной организации города и пример передового урбанизма в Волжской Болгарии и Золотой Орде. Он является свидетельством существования болгарско-татарской цивилизации и центром культурного обмена кочевых цивилизаций Азии, Европы и Ближнего Востока.

Болгар - уникальный пример взаимодействия мусульманской и христианской религий. На фоне непрекращавшихся межрелигиозных конфликтов и столкновений, которыми была переполнена вся средневековая история Европы и Азии, в Болгаре мирно жили приверженцы различных конфессий. Многочисленные археологические артефакты и сведения письменных источников убедительно подтверждают проживание в Болгаре русского населения, существование армянского кладбища, христианской церкви, известной под названием Греческая палата, других не мусульманских памятников. Эта уникальная традиция межконфессионального мира, корни которой уходят к древнему Болгару, активно проявлялась и в дальнейшем - в период Золотой Орды и Казанского ханства. И в современном Татарстане она является важнейшим фактором поступательного и динамичного развития республики.

Менялись эпохи, но сформировавшиеся в Болгаре парадигмы культуры и духовной жиз- ни на многие века определили не только традиции, нормы морали в Поволжье и Приуралье, но и положили начало современному татарскому этносу, другим многочисленным народам этого региона.

На протяжении веков Болгар оказывал разнообразное воздействие на развитие многих сфер жизни Восточной Европы и в целом Евразии. Этот город - выдающийся пример удивительно продуманной организации городского хозяйства, причина и условие активного градостроительства в регионе, что, несомненно, ставит его в ряд с самыми развитыми городами средневековой Европы.

Культура и духовная жизнь, сформировавшиеся в условиях болгарского и татарского цивилизационного проекта, определили ценности и обычаи, характер наследия, правила и законы жизни в регионе. Трансформируясь и преображаясь в эпохи Золотой Орды и Казанского ханства, во времена Московского царства, Российской империи, Советского Союза, они были сохранены в традиционной культуре татарского народа, подвергнуты изучению и осмыслению в профессиональной сфере. В настоящее время Болгарский историко-археологический комплекс является единственным подлинным материальным следом существования Волжской Болгарии и Золотой Орды периода ее расцвета.

Занимая исключительно важный район Евразии, расположенный на пересечении торговоэкономических, культурных и политических коммуникаций, Болгар стал необходимым передаточным звеном в цивилизационных контактах между Востоком и Западом, Севером и Югом, оседлыми и кочевыми культурами, между мирами Леса и Степи. Результатом этих процессов стало создание неповторимого облика традиционной культуры, отразившегося в развитии хозяйства, технологий, градостроительства, архитектуры, монументального и прикладного искусства, духовной культуры региона.

Ярким и уникальным выражением идей культурного взаимодействия и взаимовлияния, в результате реализации которых проявился самобытный и неповторимый характер культуры Волжской Болгарии и Золотой Орды, стал Болгарский историко-археологический комплекс, который на протяжении десяти с лишним веков представляет собой зримое воплощение градостроительной, культурной и ландшафтно-преобразующей деятельности, а также последующего осмысления таковой в области 
духовной культуры, фольклора, научных знаний.

Результатом этих процессов, имеющих для региона Поволжья и Приуралья истоки в культуре исторического Булгарского государства, стал продолжающийся и сейчас взаимообмен ценностей, порожденных в процессе межкультурных, межрегиональных и межэтнических контактов, в значительной степени обогативший культуру региона и мировую культуру в целом.

Комплекс характеризуют такие черты, как всеобщность, целостность, аутентичность и взаимовлияние культур не только в материально-архитектурном, бытовом, стилевом уровнях, декоративно-прикладном искусстве, но и духовной сфере и нематериальном наследии идеологии, языке, письменности и литературе, фольклоре, в единстве идей, символов, норм и образов.

\section{Критерий VI.}

Многообразие непрерывной многовековой культурно-духовной и сакральной жизни на исторических территориях Болгарского комплекса и в регионе подтверждается многочисленными уникальными данными. Приведенные ниже факторы определяют роль комплекса как выдающегося центра, связанного с событиями, традициями, идеями и произведениями, соответствующими Критерию VI, и в полной мере отражают Выдающуюся Универсальную Ценность Болгара.

Со времени официального принятия ислама волжскими болгарами в 922 г. Болгар на протяжении многих столетий остается сакральным местом, а его памятники объектами религиозного поклонения мусульман не только Татарстана, но и России. Это место обладает особой духовной аурой, являющейся нематериальным наследием высочайшего уровня. А для многомиллионного татарского народа Болгар олицетворяет духовное единство, древнюю политическую и религиозную столицу.

Активные торгово-экономические контакты Поволжья и Приуралья со странами Центральной Азии - Хорезмом и государством Саманидов - создали благоприятные возможности для проникновения на эту территорию мусульманских проповедников и возникновения устойчивой уммы. Автор начала X в. Ибн Русте (903 г.) пишет о наличии в поселениях болгар мечетей и медресе. В ставке болгарского правителя Алмуша, принявшего мусульманское имя Джафар ибн Абдуллах, был специальный штат духовен- ства, включая муэдзина. Посольство Багдадского халифата, вошедшего во Всемирную историю под именем Ибн Фадлана, способствовало официальному принятию ислама и дипломатическому признанию Болгарии как мусульманского государства. Не только в восточных, но и русских, западноевропейских источниках имя волжских болгар, а затем татар прочно ассоциировалось с понятием «мусульманство».

Принятие ислама привело к тому, что древнетюркская руническая письменность болгар заменялась арабским шрифтом. В тех условиях переход Болгарии на арабскую вязь был более предпочтителен, так как открывал широкие возможности выхода болгарской науки и культуры на международный уровень. Болгария активно включается в международные экономические и культурные связи - прежде всего со странами мусульманского Востока. Постепенно арабский язык наряду с болгарским становится языком болгарской науки и дипломатической переписки, а фарси (персидский) наряду с поволжским тюрки - языком болгарской поэзии [Валеев].

Усиление торговых и экономических связей со странами Востока привело к распространению арабской письменности и в системе образования болгар. Основным материалом письменности в Волжской Болгарии и Золотой Орде служила бумага, привозимая из далекого Китая и Самарканда. Пергамент же, как у западных народов, для письма применялся реже. Этим и объясняется плохая сохранность памятников письменности древнеболгарского и золотоордынского периодов. Ислам придал новый импульс ускоренному развитию болгарской науки и культуры в целом. На рубеже XI-XII вв. в Болгарии жил ученый - историк, главный судья Якуб ибн Нугман, автор книги «История Болгарии», которую высоко оценил арабский путешественник из Испании, географ Абу-Хамид аль Гарнати (аль Андалуси), посетивший великий город в 1135 г.

Болгаро-татарская просвещенность пользовалась настолько высоким авторитетом и признанием, что ученый Ходжа Ахмед Болгари в XI в. был назначен на пост учителя и наставника одного из могущественных монархов мира султана Махмуда Газневи. Недаром Болгарию называли «царством разума» и «золотым троном Востока». Переехав из Болгарии в Афганистан, Ходжа Ахмед Болгари врачует в городе Газни. Он прославился своими философскими и историческими трактатами. Среди них наи- 
большей известностью пользовались «Тарихател Болгария» («История Болгарии»), «Фэнандел Болгария» («Наука в Болгарии»), «Жэмигыль Болгария» («Философия Болгарии»). В 1971 г. над его могилой был построен мавзолей (дюрбе) из белого мрамора.

Высокий уровень мусульманской городской культуры обусловил активную деятельность и других просветителей, педагогов, ученых. Во второй половине XI - начале XII в. здесь жил и творил философ и историк Хамид бин Идриси аль-Болгари, в первой половине XII в. - историк Якуб бин Нугман аль-Болгари, богослов Сулейман бин Давуд аль-Саксини (XI-XII вв.), фармакологи Ходжа аль-Болгари (XI-XII вв.), а также братья Таджддин и Хасан бин Юныс (XIII в.). В первой половине XIV в. жил известный законовед Бурхан-ад-дин Ибрахим альХанафи, автор книги «Основы дискуссий» [Baлеев, Ситдиков, Хайрутдинов].

В Великом Болгаре несли свет знаний многочисленные исламские учебные заведения, в мечетях проповедовали знаменитые богословы, философы, мыслители писали научные трактаты, а поэты создавали свои замечательные произведения. И сегодня далеко за пределами России известны труды болгарских ученых по медицине, астрономии, математике, другим наукам.

Известны также крупные религиозные проекты. Так, Бейхаки (XI в.) сообщает о посылке денег правителем болгар в 415 году по хиджре (1024/1025) в область Нишапура для строительства двух мечетей в Себзеваре и Хосровджерде и «удивительных даров» для государя Хорасана. Множество сведений о передвижении религиозных проповедников-суфиев, указания на происхождение целого ряда видных богословов, правоведов и медиков, достигших признания во всем мусульманском мире, торговые и дипломатические контакты со странами Востока носили регулярный и стабильный характер [Измайлов].

В исторической памяти татарского народа сохранилось предание о прибытии трех сподвижников пророка Мухаммада в Болгары, о чудесном исцелении дочери царя Болгар Туйбикэ, о принятии Ислама царем Болгар и его окружением. Как утверждается в старинной болгарской рукописи, пересказанной в XIX в. ректором Казанского университета, ученым и врачом, почетным гражданином г. Казани, немцем по происхождению Карлом Фуксом, начало этому было положено в 9 году хиджры, когда
Пророк Мухаммед стал рассылать своих сахабов (сподвижников) к народам и государствам мира для распространения ислама. Три таких сахаба Пророка, имамы Абдур-Рахман - сын Зубайра, Талха ибн Гусман, Зубайра - сын Джагда (в вашем прошлогоднем буклете - Абдрахман ибн Зубайра, Талха ибн Гусман, Зубайра ибн Джагда), прибыли с миссией дагвата (призыва к исламу) к болгарам. Как проходила их миссия среди болгар, довольно подробно описано Карлом Фуксом. До второй половины XVIII в. в Болгаре в сохранности были могилы сподвижника пророка и 33-х «табигинов» (людей, принявших ислам через сподвижников) [Валеев].

Ярким свидетельством распространения ислама являются мусульманские могильники и погребальная обрядность. На территории Волго-Уралья в настоящие время исследовано более 80 грунтовых могильников, из которых 52 относятся к домонгольскому периоду (X-XIII вв.), а остальные к золотоордынскому времени. Мусульманский погребальный обряд становится доминирующим с рубежа X-XI вв. до середины XIII в. и приобретает единообразные «канонические» формы. В золотоордынский период в связи с переменами в религиозной практике происходят изменения в погребальном обряде и начинается установка каменных эпиграфических памятников и сооружений мавзолеевдюрбе. Надписи на средневековых эпиграфических памятниках, сохранившихся на территории городища, в начале 1840 гг. исследовал известный русский ориенталист И. Н. Березин. В его книге «Болгар на Волге» впервые были опубликованы интерпретация и анализ надписей.

C XV в. Болгар превращается в центр религиозного поклонения и паломничества к этим святым местам. Об этом образно пишет российская императрица Екатерина II сначала в письме графу Н. И. Панину, а затем великому французскому философу-просветителю Вольтеру. В 1767 г. она по пути из Казани в Симбирск посетила Болгар и написала, что «татары великое почтение имеют к сему месту и ездят богу молиться в сии развалины». В 1838 г. выдающиеся русские художники братья Г. Г. и Н. Г. Чернецовы, посетив Болгар, отметили: «<..> место, в котором < .. >погребены их пророки; татары почитают их за святых и из отдаленных мест приезжают на поклонении к ним $<\ldots>$ из Уфы, Оренбурга, Казани, <..> Бухарии, и <..> Хивы. В числе молельщиков жите- 
ли болгарские видели черных (темнокожих): они здесь дня по два и более, привозя иногда с собой нарочно мулл для отправления своих религиозных обрядов».

Болгар и его территория ярко иллюстрируют развитие ислама, его институтов, догматики, правовых школ-мазхабов, этапов ее эволюции в составе Волжской Болгарии, Золотой Орды, Казанского ханства, Российского государства, специфику развития сообщества российских мусульман и характер их отношений с государством. Объект имеет большую духовную и религиозную ценность и является воплощением целого спектра нематериальных ценностей, которые непосредственно указывают на Выдающуюся Универсальную Ценность Комплекса. И сегодня на территории Белой мечети, а по мусульманским праздникам - в Соборной мечети, у Малого минарета и Ханской усыпальницы читается намаз, сохраняются неизменные традиции духовности и святости места. Белая мечеть и Памятный знак стали символами возрождения духовности после долгих лет господства атеизма и тоталитаризма, проведения мусульманских обрядов и ритуалов.

Образовательная деятельность Исламского центра, созданного в настоящее время в Белой мечети, обеспечивает сохранение традиций, принципов обучения и получения знаний, тем самым повышая значимость объекта. Выдающаяся Универсальная Ценность включает такие ценностные аспекты, как духовность, паломничество к святыням, исполнение обрядности и праведность, целый ряд исторических событий (принятие Ислама в 922 г. и приезд Посольства Ибн Фадлана, столичность и т. д.) [Валеев, Ситдиков, Хайрутдинов].

Соборная мечеть с Большим минаретом (XIII-XV в.) и Успенская церковь (XVIII в.), расположенные рядом, являются свидетельством и показателем толерантности и мирного сосуществования мусульманской и христианской религий. Болгар как яркий образец развития ислама в регионе подтверждает многовековые традиции межконфессиональной толерантности, добрососедства и взаимного уважения народов Волго-Уральского региона и Российской Федерации. В условиях многоконфессионального и поликультурного общества, традиции российского ислама, имеющего и многовековый опыт сосуществования с православными и другими религиями, получил новый импульс.

Со времен Казанского ханства Болгар приобрел значение выдающегося культового и ду- ховного центра, священного места поклонения древним постройкам, которые на долгие времена сохранились в болгаро-татарской устной народной традиции как памятники ислама и болгаро-татарской государственности. Яркие картины городской жизни Болгара нашли место в блестящих образцах средневековой болгаротатарской литературы: поэме Кул Гали «Кыйсса-и-Йусуф», 800-летие создания которой было отпраздновано по линии ЮНЕСКО, а также в эпосе «Идегей», народных легендах и преданиях. К героическому и лирическому образу Болгара не раз возвращались в своих произведениях татарские поэты Мухаммедьяр (XVI в.), Мовля-Колый (XVII в.). Настоящим источником творческого вдохновения стал Болгар для татарских просветителей и основателя татарской исторической науки Ш. Марджани [Валеeв].

Татарский народ помнил, знал и воспевал город Болгар - «Шэхри Болгар» - в своих исторических баитах, легендах, мунаджатах, называя его местом святых («изгелэр жире»). Во времена Казанского ханства, да и в более поздние времена вблизи Болгар располагалось татарское поселение, жителям которого вменялось в обязанность сохранение мавзолеевдюрбе и других выдающихся памятников.

Влияние Болгара на сознание многих поколений татар было настолько велико, что обычай добавлять к имени нисбу «альБолгари» сохранялся в среде татарской интеллигенции до начала XX века. Живая связь татарского народа с Болгаром не прерывалась в течение столетий. До сегодняшнего дня в традиционной культуре казанских татар продолжают бытовать ни с чем не сравнимые мотивы болгарских орнаментов, традиции хозяйствования и домашней культуры.

Уникальная историческая, культурная, духовная аура Болгара во все времена притягивала к себе выдающихся путешественников, писателей, поэтов, ученых, художников, краеведов, архитекторов, реставраторов. Среди них поэт Кул-Гали, ханы Бату и Берке, император Петр I, императрица Екатерина II, выдающиеся российские художники И. И. Шишкин, А. К. Саврасов, братья Н. Г. и Г. Г. Чернецовы и многие другие, оставившие ценные свидетельства, описания, рисунки, чертежи, планы зданий и руин древнего города.

Бытование Болгарского городища в X-XV вв. и на том же месте поселения XV-XVI вв., засвидетельствованное археологическими объ- 
ектами и артефактами на фоне последовательно сменяющих друг друга исторических эпох (период, предшествующий строительству города, время домонгольской Волжской Болгарии, 3олотой Орды, Казанского ханства), в XVII-XIX вв. закрепленное в памятниках нематериальной культуры в качестве народных легенд и преданий, существующее и в настоящее время как факт культового почитания и сохранения руин болгарских архитектурных памятников (православный монастырь и Успенская церковь в XVIII в.), являются достаточным свидетельством существования устойчивой единой историко-культурной традиции, отражающей своеобразие Болгара как выдающегося культурного района мира, оказывающего на протяжении пятнадцати и более веков устойчивое воздействие на развитие культуры, искусства, архитектуры и градостроительства.

Духовное наследие Болгар, яркая и насыщенная история столицы Волжской Болгарии и Золотой Орды дали мощный толчок для развития татарского изобразительного, театрального и музыкального искусства, художественной литературы и поэзии, национальной культуры в целом. В последние годы культурное наследие Болгар послужило основой для создания новых выдающихся образцов национальной культуры. Среди наиболее интересных произведений поэма «Клятвенная чаша» (2005), балет «Сказание о Йусуфе» (2001), балет «Золотая Орда» (2013), опера «Черная палата» (2013) и др. Получили народное признание исторические романы Нурихана Фаттаха, Мусагита Хабибуллина, Романа Вахитова и многих других татарских писателей, произведения художников Баки Урманче, Равиля Загидуллина, Канафи Нафикова, Рифката Вахитова, Феринада Халикова и др. [Город Болгар, 1996], [Город Болгар, 2001] [Город Болгар, 2008].

И сегодня Болгар, как и на протяжении многих веков, продолжает оставаться одним из главных центров паломничества мусульман России и татарской диаспоры всего мира. Болгар приобретает важное значение межрегионального культурного центра российских мусульман, становится уникальной площадкой международного сотрудничества и является единственным музеем-заповедником, представляющим историю ислама в Российской Федерации, мусульманской культуры как части евразийской цивилизации. Прекрасными символами сохранения преемственности многовеко- вых духовных традиций Болгара являются возведенные здесь Белая мечеть и Памятный знак.

Целостность и подлинность Комплекса.

Сохранность характерных черт и уникальных ценностей, передающих Выдающуюся Универсальную Ценность этой исторической территории, ее Критериев в полной мере подтверждается ее целостностью и аутентичностью.

\section{Целостность.}

В границах памятника имеется достаточная территория, включающая все элементы, позволяющие представить ход и результаты его эволюции, сформировавшиеся в процессе жизнедеятельности различных этносов в Болгаре и регионе в V-XXI вв.

Болгарский историко-археологический комплекс не имеет аналогов в мире как ценное и уникальное свидетельство существования Волжской Болгарии и Золотой Орды. Систематические исследования ученых, которые почти непрерывно осуществляются здесь вот уже 150 лет, дают возможность детально реконструировать все многообразие жизни древнего города и его округи.

Результаты этих исследований позволили получить подробные сведения о 30 кирпичнокаменных сооружениях, на 16 из которых осуществлена консервация и музеефикация для туристического показа. Остальные объекты были законсервированы.

Архитектурно-археологическая информация по этим памятникам сохранилась в виде подробных научных отчетов. Все эти сведения являются неисчерпаемым источником для исследователей при создании научных трудов, которые, в свою очередь, стали основой разработанной программы по музеефикации памятников Болгара до 2019 г.

97\% территории комплекса не затронуто археологическими исследованиями и формирует целостный культурный слой памятника. Сoвременные археологические исследования проводятся с использованием преимущественно неразрушающих методов и соответствуют международным стандартам.

Болгар - это свидетельство формирования и развития уникальной практики государственной и общественной форм охраны памятников истории и культуры в стране и мире. Влияние болгарско-татарской цивилизации на историю и развитие многих народов Евразии было настолько значимым, что впервые в истории России на государственном уровне императором 
Петром I в 1722 г. был принят указ о сохранении и реставрации Большого минарета Соборной мечети. Именно с этого времени формируется государственная форма охраны древностей в России и берут свое начало охраннореставрационные работы на памятниках городища.

Подтверждением уникальности Болгарского комплекса, которая безоговорочно признавалась учеными и широкой общественностью, стал первый в истории музейного дела России проект создания на территории памятника в середине 1850-х гг. археологического музеязаповедника. Со второй половины XIX в. существовали и активно работали государственные и общественные институты, обеспечивавшие сохранение и изучение памятников Болгара. С 1969 г. объекты комплекса объединены историко-архитектурным музеемзаповедником. А статус памятника федерального значения, охраняемого государством, позволил сохранить в хорошем состоянии и полноте все архитектурные объекты и культурные археологические слои, связанные со средневековой жизнью города.

Болгарское городище является ценнейшим и неиссякаемым источником для постоянного пополнения знаний о блестящей истории и культуре Болгарско-татарской цивилизации. На этой территории за 300 лет отработана уникальная методика изучения памятников комплекса. Выдающимся фактом является начало систематических археологических исследований объекта с середины XIX в., на основе которых в первой половине XX века сложилось «болгароведение» как самостоятельное научное направление в археологии.

Осуществляется комплексная реставрация предметов, извлекаемых в ходе раскопок. Для вновь выявленных археолого-архитектурных объектов применяются методы консервации с учетом сохранности объекта и специфики его расположения на городище. Консервация новых объектов осуществляется путем создания на поверхности сочетаний сооружений без физической связи с оригиналом («двухмерная консервация»), тем самым расширяются возможности для туристов и паломников. Это создало условия для осуществления стратегии сохранения археологической целостности, осторожного подхода к раскопкам, сохранения целостности территории комплекса, предотвращающего возможность сокращения аутентичности (подлинности) объекта.

\section{Подлинность.}

Определяющим и значимым атрибутом Комплекса являются сохранившиеся валы и рвы высотой до 5м на всей протяженности объекта. Они ярко демонстрируют целостность и аутентичность территории Комплекса и позволяют визуализировать и раскрыть объект в пределах исторических границ крепостных сооружений XIV в. Исходя из II и VI критериев, анализ и характеристика ценностей Комплекса, его подлинность хорошо раскрывается в широком контексте исторического отрезка времени Евразии в 1500 лет.

За этот отрезок времени территория объекта являлась уникальным центром пересечения последовательных хронологических и пространственных характеристик, отражающих материальную, духовную и архитектурную ценности, признаки культурного ландшафта и технологий финно-угорской, булгарской, татарской, славянской и других социокультурных общностей мусульманской и православной конфессий и культур, различных эпох правления и государств, взаимодействия и взаимовлияния в урабанизационном, архитектурном и ином культурном и художественном самовыражении. Интеграция, синтез и взаимовлияние исторических, культурных и религиозных ценностей выразилось в аутентичности культурного ландшафта, исторической топографии, культурного слоя, вала и рва, археологических материалов и архитектурных памятников, отражающих 1500-летнюю историю территории.

Еще до болгар на Коптеловом бугре уже существовали укрепления, сооруженные населением именьковской культуры (V-VII вв.). В $\mathrm{X}$ в. крепость болгарами была значительно расширена. Вдоль внутреннего рва Болгар был окружен деревянной стеной. Одновременно с созданием укреплений была заселена и обширная территория в непосредственной близости.

К XI в. расширился ремесленный посад Болгара, где активно развивались железоделательные, медеобрабатывающие, кожевенные и другие производства. Так постепенно формировался средневековый феодальный город. Вдоль широкой и чрезвычайно живописной волжской террасы были рассыпаны многочисленные поселки. А на самом берегу Волги шумел восточный базар - Ага-Базар-торжище, который упоминается в письменных источниках начала $\mathrm{X}$ в. В дальнейшем активное развитие Болгара как международного торгового пункта 
преемственно перешло в XV в. к Казани, в XVI в. к Нижнему Новгороду и позже к Москве.

В XI - начале XII в. происходило активное развитие ремесленного посада, на окраине города возникли железоплавильные мастерские с сыродутными горнами. К концу домонгольского периода площадь посада уже втрое превышала площадь первоначального города. Именно к этому времени в территорию города был включен и ближайший южный пригородный поселок. Стремительно росло и население города, широко осуществлялось жилое строительство.

До конца домонгольского периода посад города не был укреплен, и только в конце XII начале XIII в. была создана система обороны, окружавшая более густо застроенную часть. Вторая половина XIII - начало XIV в. - это время восстановления и расцвета Болгара. Как старый экономический центр Поволжья, он стал главным городом золотоордынских ханов XIII в. В течение раннезолотоордынского периода раздвинулись границы города, восстановилось и расширилось ремесленное производство, укрепились торговые связи, было начато монументальное строительство.

К 30 гг. XIV в. окончательно сложился архитектурный ансамбль центра Болгара, его настоящей жемчужиной стала Соборная мечеть с Большим минаретом. Общественный центр города украшали и другие уникальные архитектурные сооружения - ханский дворец, Восточный и Северный мавзолеи, известные также под названием «Церковь св. Николая» и «Монастырский погреб». По материалу кладки, техническим и декоративным приемам болгарская Coборная мечеть с Большим минаретом имеет схожие черты с каменными постройками Закавказья, Крыма, Малой Азии, Северной Месопотамии. В то же время в архитектуре этого уникального памятника нашли отражение объемнокомпозиционные черты, присущие постройкам Средней Азии золотоордынского периода, а также местные традиционные приемы, использовавшиеся при строительстве Соборной мечети в Биляре и крепости-мечети в Елабуге. В настоящее время вид центральной части комплекса соответствует иконографическим документам XVIII-XIX вв. Для туристов и паломников доступна смотровая площадка минарета, откуда открывается прекрасный вид на Болгарское городище и его архитектурные памятники, безбрежное водное пространство Волги и удивительно живописные зеленые луга с перелесками.
Еще одним сооружением этого времени, которое является важнейшим элементом сложившегося общественного центра города, является Черная палата. Построенное в XIV в. из белого известняка здание, по структуре и художественной трактовке стоящего ближе всего к среднеазиатской архитектуре, - единственное сохранившееся гражданское сооружение этого периода. Точное назначение Черной палаты не установлено, предположительно это дом суда, медресе или странноприимный дом (ханака).

Все монументальные здания древнего Болгара имеют свое, ярко выраженное своеобразие. Местные архитекторы, освоив и используя традиции исламской архитектуры Арабского халифата, Бухары, Хорезма, Дербента, с другой стороны - архитектуру Хазарского Каганата, Государства Сельджукидов, Византии, Армении, Индии и доставшееся им богатейшее культурное наследие доисламских языческих культур, выработали собственные эстетические концепции, своеобразные приемы и методы, обусловленные местными климатическими условиями. Сложился своеобразный растительный архитектурный декор, основанный на местных строительных материалах, доисламских и исламских духовных традициях и влияниях.

Воплощенные в камне здания мечетей, минаретов, мавзолеев и бань не только определили облик города Болгара в XIII-XV вв., но также повлияли на архитектуру Казанского ханства, традиции которой имели затем преемственное развитие и в эпоху присоединения его к России. Даже после того как жизнь в городе Болгаре угасла, воспоминание о его архитектуре сохранилось в татарских народных преданиях, тюрко-татарском эпосе «Идегей», а руины зданий совместно с окружающим ландшафтом стали местом религиозного поклонения, эстетического любования, а затем и научного изучения.

К юго-западу от общественного центра Болгара существовал торговый двор, где функционировало ювелирное стеклоделательное производство. В подгорной и заречной части, по берегам р. Меленки в это время существовали городские бани. К настоящему времени в Болгаре изучены полностью остатки шести построек общественных бань. Имея много общих конструктивных особенностей, они тем не менее различаются расположением, размерами, планировочными особенностями, материалом и временем строительства. Бани Болгара имеют схожие черты с типичными восточными хаммамами. 
Юго-восточные районы Болгара были застроены богатыми кирпичными домами с подпольными системами отопления и представляли собой места, где проживала городская знать. После 1361 года на большей части этой территории возникли городские кладбища и культовые постройки - комплекс усыпальниц и Малого минарета. Распространение некрополей наблюдается и в южных районах города. Вообще среди монументальных каменных построек Болгарского историко-археологического комплекса особое место принадлежит ритуальным сооружениям - мавзолеям - дюрбе. Кроме Восточного и Северного мавзолеев, Ханской усыпальницы, на территории комплекса расположены еще 9 мавзолеев, сохранившихся на уровне фундаментов, и 4 мавзолея, скрытых под холмами. Мавзолеи Болгара построены из известняка в середине XIV - начале XV века. Найденные и исследованные в них захоронения свидетельствуют, что это мусульманские погребения знатных и особо почитаемых лиц.

В западном и северо-западном районах Болгара функционировали многочисленные ремесла - металлургические, гончарные, меднолитейные, ювелирные. Большой концентрацией производственных комплексов отличается район Галанского озера, на берегах которого археологами обнаружены большие запасы серой глины. А многочисленные находки обломков болгарской посуды, керамических горнов дают возможность предположить, что здесь было сосредоточено массовое гончарное производство в период расцвета города в середине XIV.

К югу от городища за валом располагался Малый городок, укрепленный рвами и валами, с парадным, оформленным каменными пилонами въездом с северной стороны и с каменной постройкой в южной части. Название «Малый городок» впервые зафиксировано в 1712 году в описи дьяка Михайлова. Считается, что это остатки недостроенного парадного комплекса или караван-сарая. Также существует предположение о его культовом назначении.

В северо-западной части к городу примыкала Армянская слобода, возникшая на месте болгарского пригородного поселка. Здесь археологами выявлены деревянные жилища и серия погребений. Полученные материалы свидетельствует о существовании здесь в XIV в. торговой христианской колонии и кладбища. Здесь же выявлены остатки каменной культовой постройки, получившей название «Греческая палата», которая является руинами христианского храма, возможно построенного как прототип Церкви Св. Богородицы (Сурб Аствацацин) в монастыре Нораванк (Армения).

Взаимодействие мусульманской и христианской религий, значительное количество археологических артефактов, связанных с ними и проживанием русского населения в Болгаре, отдельное кладбище с надгробными плитами с надписями на армянском языке, археологические остатки христианской церкви - Греческой палаты, другие зримые материальные объекты - это яркое свидетельство взаимовлияния религиозных ценностей в Болгаре. Поликультурность, ставшая неотъемлемой частью духовной жизни Болгарского государства и Золотой Орды, активно проявлялась и в период Казанского ханства и Российского государства.

Уникальность и универсальная ценность территорий, на которой расположен Болгарский комплекс, характеризуется непрерывной преемственностью историко-культурных традиций, которые сохранялись здесь на протяжении многих столетий. Ранние этапы освоения и развития этого региона подтверждаются многочисленными данными исследований, проведенных учеными на могильнике «Бабий бугор», Болгарских селищах, которые датируются V-VII вв. н. э. И в позднейшие периоды истории, после исчезновения с политической карты Болгарского государства, Золотой Орды и Казанского ханства, развитие этого края продолжалось. В начале XVIII в. возникшее как монастырская слобода Успенского монастыря село Болгары существует в своих первоначальных границах по сегодняшний день. А его архитектурная стилистика, характерный быт его жителей, несомненно, отражают многовековые историко-культурные особенности этой территории.

Неизменным остался на протяжении тысячелетия и культурный ландшафт Болгарского комплекса. С домонгольского времени существует Иерусалимский овраг. Он представляет собой важнейшую деталь исторического окружения болгарского города, и одновременно это место древнейшего поселения именьковской культуры на его территории. Овраг с древнейших времен и на всем протяжении существования средневекового города входил в систему его обороны. Ландшафт Болгарского городища сохранил свои границы до настоящего времени.

Аутентичность комплекса подчеркивается длительностью и непрерывностью существования и развития на этой территории болгаротатарской традиции, активной и масштабной 
урбанизацией региона, ускорением цивилизационных процессов для целого ряда народов Евразии. Условием сохранения уникальных объектов средневековья является создание историко-архитектурного музея-заповедника как научно-исследовательского, музейного и реставрационного центра, объединения останков всех исторических эпох и создания механизма сохранения подлинности всех атрибутов комплекса.

\section{Управление Комплексом.}

Сегодня Болгарский историко-археологический комплекс находится под защитой федерального и регионального законодательств и правительств. Любые виды работ за исключением научных исследований и музейной деятельности на территории музея-заповедника запрещены. Разработаны и утверждены Концепция и план управления Комплексом до 2019 г. и стратегия управления объектом на 20 лет, подготовка осуществлялась в рамках широких консультаций с различными правительственными и неправительственными структурами, обсуждений с депутатами, местным сообществом, Международным межведомственным научно-методическим экспертным советом Республиканского Фонда возрождения памятников истории и культуры Республики Татарстан.

Новый этап в истории Болгарского городища связан с началом реализации в 2010 г. проекта «Культурное наследие Татарстана: древний город Болгар и остров-град Свияжск», который координируется Республиканским Фондом «Возрождение». Была поставлена амбициозная задача превратить Болгарское городище в историко-культурный, музейный и духовносакральный центр, зримо подчеркивающий Выдающуюся Универсальную Ценность объекта.

Системный подход к выявлению, изучению, консервации и музеефикации памятников Комплекса является основой сохранения объекта. Установлены требования непрерывного комплексного профилактического обследования и обслуживания памятников. Реставрация объектов Болгара рассматривается как вынужденная и исключительная мера, направленная на сохранение и выявление исторических ценностей памятника. Знания, полученные в процессе исследований, накопленный опыт в области сохранения памятников археологии и архитектуры стали основой деятельности музея-заповедника, Центра по изучению болгарской цивилизации, археологическо-реставрационной базы.
В исследовательских программах настоящего времени, которые осуществляются на территории Болгарского историко-археологического комплекса, акцент сделан на использовании передовых современных технологий и методик естественно-научных дисциплин, аэрофотосъемки и обработки космической спутниковой информации. Происходит широкое внедрение современных методов точной полевой фиксации, создание и применение новых методик датирования культурных отложений, объектов и отдельных артефактов.

Особая роль в плане управления археологическими ресурсами отводится созданному в Болгаре Международному центру археологических исследований Института археологии АН РТ, призванному выполнять функции как научного, так и социального института. Он становится крупной исследовательской и научно-организационной структурой для привлечения специалистов в области изучения и сохранения археологического наследия, важной площадкой для научных дискуссий, независимой экспертной деятельности «Центра превосходства», для широкого международного сотрудничества и реализации образовательных проектов и программ. Здесь созданы все необходимые условия для проведения научных и практических форумов, рабочих семинаров, студенческой практики.

С каждым годом растет число туристов и паломников, посещающих эти заповедные исторические территории. С целью максимально полного сохранения подлинности и целостности Болгарского комплекса была принята специальная программа, и с 2010 г. за границами городища сооружены Белая мечеть, Музей хлеба, Памятный знак в честь принятия ислама, Музей болгарской цивилизации, совмещенный с Речным вокзалом и центром приема туристов. Это нестандартное решение позволило значительно снизить нагрузку на архитектурноархеологические памятники.

Важной частью современного управления Болгарским комплексом является музеефикация объектов городища и создание разнообразных по тематическому содержанию музеев, экспозиций, выставок. Стратегия развития музейной и туристической деятельностей направлена на широкое представление историкокультурного и духовного потенциала Болгара, многообразие наследия этого места, значение принятия ислама, его развитие как исторического центра российской мусульманской культуры, толерантного сосуществования с право- 
славной культурой, пересечения культур и цивилизаций.

Как и много веков назад, Болгар продолжает ярко светить на небосклоне болгаротатарской истории. Его блестящее прошлое, созданные здесь уникальные материальные, культурные, духовные ценности необычайно емко демонстрируют огромный потенциал народов, испокон веков населявших берега Волги и Камы. В исторической судьбе Болгара были периоды расцвета, подъема, которые сменялись упадком, а потом вновь неизменно начиналось возрождение. Этот во многом сакральный город никогда не прекращал своего существования, он никогда не был городом-призраком. Если и разрушался физически, то продолжал жить в сердцах людей, память о нем бережно передавалась из поколения в поколение. Сегодня он вновь оживает, его историческая судьба наполняется новыми красками и смыслами. Он вновь объединяет людей и необычайно обостряет чувство любви к своей родной земле и гордости за свою историю.

\section{Литература}

Болгарский историко-археологический комплекс. Т. 1-2. Казань, 2016.

Валеев Р. М. Болгар и Свияжск: их роль в культурном разнообразии и развитии науки Татарстана // Межконфессиональное воздействие в пространстве историч. памяти. Казань: изд. Каз. фед. ун-та, 2016. C. $461-468$.
Валеев Р. М., Ситдиков А. Г., Хайрутдинов Р. Р. Болгар - объект всемирного наследия ЮНЕСКО. Т. 1. Казань: ООО Глав дизайн, 2016. 400 с.

Город Болгар. Ремесло металлургов, Кузнецов, литейщиков. Казань, 1996. 314 с.

Город Болгар. Монументальное строительство, архитектура, благоустройство. М.: Наука, 2001. $364 \mathrm{c}$.

Город Болгар. Культура, искусство, торговля. М.: Наука, 2008. 275 с.

Измайлов И. Л. Волжская Булгария в IX - первой трети XIII века: становление социальной, религиозной и этнополитической структуры общества: автореф. дис. ... докт. истор. наук. Казань, 2013. 67 с.

Старостин П. Н. Предболгарские памятники на территории Болгарского городища // Город Болгар. Очерки истории и культуры. М.: Наука, 1987. С. 8998.

Тизенгаузен В. Г. Древности, найденные близ г. Спасска Казанской губернии // Древности: Тр. MAO. M., 1873. T. III.

Хайрутдинов Р. Р. Выдающаяся универсальная ценность Болгарского историко-археологического комплекса - уникального объекта культурного и природного наследия Республики Татарстан // Сборник трудов международной научноисторической конференции им. Академика Л. Блюментростра. Берлин: Wissenschaftliche Welt, 2014. C. $97-101$.

Хлебникова Т. А. История археологического изучения Болгарского городища. Стратиграфия. Топография // Город Болгар. Очерки истории и культуры. М.: Наука, 1987. С. $32-88$.

\title{
ЮНЕСКО НЫН БӨТЕНДӨНЬЯ МӘДӘНИ МИРАСЫ ОБЪЕКТЫ БУЛАРАК БОЛГАР \\ (БОЛГАР ДӘУЛӘТ ТАРИХ-АРХИТЕКТУРА МУЗЕЙ-ТЫЮЛЫГЫН ТӨЗУНЕН 50 ЕЛЛЫГЫНА)
}

\author{
Рафаэль Миргасыйм улы Вәлиев, \\ Казан федераль университеты, \\ Россия, 420008, Казан ш., Кремль ур., 18 нче йорт, \\ valeev_rm@inbox.ru.
}

\begin{abstract}
Мәкалә Болгар тарих-архитектура музей-тыюлыгының 50 еллыгына багышлана (1969). Хезмәттә Татарстан АССРда татар халкының тарихи һәм мәдәни һәйкәлләрен өйрәнү, саклау, консервацияләү һәм реставрацияләү буенча комплекслы эш алып баручы беренче оешманы булдыру тарихына кагылышлы материаллар системага салынган. Автор Болгарны ЮНЕСКО Бөтендөнья мирасы комитеты экспертларының музей-тыюлыкны кешелек тарафыннан танылган дөнья һәйкәлләре арасына кертү карары өчен нигез булган универсаль кыйммәтләренә ТР галимнәре тәкъдим иткән дәлилләр системасын китерә.
\end{abstract}

Төп төшенчәләр: Болгар, Күренекле универсаль кыйммәт, Критерийлар, Бөтенлек, Чынлык, Аутентиклык, Яклау һәм Идарә итү. 